\title{
THEMATIC PROGRESSION IN JAKARTA POST AND 'KOMPAS' NEWSPAPER EDITORIALS: A COMPARATIVE STUDY ON TEXT COHERENCE STRATEGY
}

\author{
Neni Triyana ${ }^{1}$, Safnil Arsyad ${ }^{2}$, Arono ${ }^{3}$ \\ ${ }^{123}$ English Education Postgraduate Programe \\ Bengkulu University, Indonesia \\ e-Mail: nenie80@gmail.com \\ safnilarsyad@gmail.com dank aron@yahoo.com
}

\begin{abstract}
:
This research objective are analyze the common pattern in Jakarta Post and 'Kompas' newspaper editorials. The research method used was a mixed method. The research instrument is checklist. The procedure classifies all objects (10 texts Jakarta Post newspaper editorials and 10 texts 'Kompas' newspaper editorials) on the thematic progression patterns are checklist. The result shows that the thematic progression in Jakarta Post and 'Kompas' newspaper editorials are found 3 patterns of thematic progression; 10 texts derived theme; 8 texts Constant progression, and 2 text linear progression. The different on thematic progression in Jakarta post and 'Kompas' newspaper editorials is difference, the difference of sequence in the patterns between Jakarta Post and 'Kompas' newspaper editorials. The Conclussion Thematic Progression in Jakarta Post and 'Kompas' newspaper editorials are derived theme and Constant progression.
\end{abstract}

Keywords:Thematic Progression, Jakarta Post, 'Kompas', Editorials, Checklist

Abstrak: Tujuan penelitian ini adalah menganalisis pola umum di Jakarta Post dan editorial surat kabar 'Kompas'. Metode penelitian yang digunakan adalah metode campuran. Instrumen penelitian ini adalah ceklist. Prosedur penelitian mengklasifikasikan semua objek (10 teks tajuk rencana di koran Jakarta Post dan 10 teks tajuk rencana di koran 'Kompas'). Pada pola perkembangan tematik adalah daftar ceklist. Hasilnya menunjukkan bahwa tema dalam Tajuk rencana di koran Jakarta
Postdan 'Kompas' ditemukan 3 pola perkembangan tematik; 10 teks berdasarkan tema, 8 teks Perkembangan konstan, dan 2 tek perkembangan linier. Perbedaan antara tajuk rencana di koran Jakarta dan 'Kompas' ada perbedaan, perbedaannya itu ada pada urutan pola antara tajuk rencana di koran Jakarta Post dan 'Kompas'. Kesimpulan pengembangan Tematik tajuk rencana di koran Jakarta Post dan 'Kompas' adalah berasal dari tema dan perkembangan Konstan.

KATA KUNCI: Pengembangan Tematik, Jakarta Post, 'Kompas', Editorials, Ceklist 


\section{INTRODUCTION}

Texts are any of various genres types linguistics forms. They can be spoken and written. Spoken texts are those like speeches. News at Television and radio, conversation, and other oral communication. While written texts are newspapers, books, novels, letters, and other written languages Brown (1994).

Thematic Progression is a significant contribution to text coherence. Coherence is the logical connections which readers perceive in a written or oral text. It refers to the understanding that the reader derives from the text. A text is said to have global coherence, if it hangs together as a whole, which is referred to as "discourse flow" by Halliday (2014). Discourse flow is managed by two related systems such as theme or thematic progression and structure. The theme is often given information (familiar to the reader of from the context), and the Rhyme consists of new information. Fries (1995) notes the theme orients reader to message which is perceived and provides a framework for messages interpretation. Thematic progression is another way of promoting coherence text, by succession of themes across sentences and paragraph. Different thematic progression serve different roles an creating a strong topical focus in a text, allowing new information to be developed or introducing a number of different information pieces.

Thematic Progression is a significant contribution to text coherence. Coherence is the logical connections which readers perceive in a written or oral text. It refers to the understanding that the reader derives from the text. A text is said to have global coherence, if it hangs together as a whole, which is referred to as "discourse flow" by Halliday (2014). Discourse flow is managed by two related systems such as theme or thematic progression and structure. The theme is often given information (familiar to the reader of from the context), and the Rhyme consists of new information. Fries (1995) notes the theme orients reader to message which is perceived and provides a framework for messages interpretation. Thematic progression is another way of promoting coherence text, by succession of themes across sentences and paragraph. Different thematic progression serve different roles an creating a strong topical focus in a text, allowing new information to be developed or introducing a number of different information pieces.

Danes (1974) identifies three patterns of thematic progression for example Pattern 1 represents a linear progression where theme follows from preceding Rhyme and so on; Pattern 2, a progression where each theme is derived from a more general macro-theme; and Pattern 3, a constant progression where the theme is kept from clause to clause.

Jakarta Post is a English language newspaper in Indonesia. The paper is owned by PT Bima Media Tenggara, and the head office is in the national's capital, Jakarta. The Jakarta Post was started as collaboration among four Indonesian media under the urging of information Minister Ali Murtopo and politician Jusuf Wanadi. And then the Jakarta Post is going online. This newspaper also available on the web. The Jakarta Post.com is more than just extension of the information in Indonesia. 
Kompas is an Indonesia national newspaper, published by Kompas Gramedia. It has been in existence since June, 1965. Kompas also manages an online portal KOMPAS.com, which contains updated news and the digital version of the paper.

Comparative Study a concepts thematic progression in Jakarta Post and
'Kompas' Newspaper Editorials. Coherence Strategy is one where the elements strategy and reinforce each other thematic progression the pattern: linear, derived, and constant progression. A coherence strategy produces more value, with each element of the strategy producing more because of the present of the other elements. but in this research just restricted three pattern.

\section{There}

are studies on these topics such as from Wei (2016). It analyzed the speakers and writers organize their messages in a way which make them integrate into the unfolding text smoothly and it makes a significant contribution to the coherence of a text. It can connections that listeners' or readers' perception in a written or oral text.

The second research on this topic was conducted by Eva's (2013) She found thematic progression letter analysis on Reader's forum in Jakarta Post. She found that: 1) Zigzag Theme, 2) Re-iterate theme, 3) Blending between those thematic development and 4) No thematic development.

The last study on this topic was conducted by Valeria (2015) she analyzed The schematic structure of news item text. Newspaper and article text from Jakarta Post. She found the similarity of texts is used for declarative mood type in the two tests, but there is only one interrogative mood type found in The Jakarta Post (TJP).

The studies above are important research to know about the thematic progression. However, there is no comparative study about thematic progression in Jakarta Post and 'Kompas' Newspaper Editorial. Research will analyze the text in Jakarta Post and 'Kompas' Newspaper Editorials used the pattern 1, 2, and 3. According Danes (1974) identifies three patterns of thematic progression: Pattern 1 represents a linear progression where the theme follows from the preceding Rheme and so on; Pattern 2, a progression where each theme is derived from a more general macro-theme; and Pattern 3, a constant progression where the theme is kept from clause to clause.Texts are any of various genres types linguistics forms. They can be spoken and written. Spoken texts are those like speeches. News at Television and radio, conversation, and other oral communication. While written texts are newspapers, books, novels, letters, and other written languages Brown (1994).

Thematic "Progression is a significant contribution to text coherence. Coherence is the logical connections which readers perceive in a written or oral text. It refers to the understanding that the reader derives from the text. A text is said to have global coherence, if it hangs together as a whole, which is referred to as "discourse flow" by Halliday (2014). Discourse flow is managed by two related systems such as 
theme or thematic progression and structure. The theme is often given information (familiar to the reader of from the context), and the Rhyme consists of new information. Fries (1995) notes the theme orients reader to message which is perceived and provides a framework for messages interpretation. Thematic progression is another way of promoting coherence text, by succession of themes across sentences and paragraph. Different thematic progression serve different roles an creating a strong topical focus in a text, allowing new information to be developed or introducing a number of different information pieces.

Danes (1974) identifies three patterns of thematic progression for example Pattern 1 represents a linear progression where theme follows from preceding Rhyme and so on; Pattern 2, a progression where each theme is derived from a more general macro-theme; and Pattern 3, a constant progression where the theme is kept from clause to clause.

\section{Jakarta}

Post is a English language newspaper in Indonesia. The paper is owned by PT Bima Media Tenggara, and the head office is in the national's capital, Jakarta. The Jakarta Post was started as collaboration among four Indonesian media under the urging of information Minister Ali Murtopo and politician Jusuf Wanadi. And then the Jakarta Post is going online. This newspaper also available on the web. The Jakarta Post.com is more than just extension of the information in Indonesia.

\section{Kompas $\underset{\substack{\text { is an } \\ \text { Indo }}}{ }$} nesia national newspaper, published by Kompas Gramedia. It has been in existence since June, 1965. Kompas also manages an online portal KOMPAS.com, which contains updated news and the digital version of the paper.

Comparative Study a concepts thematic progression in Jakarta Post and 'Kompas' Newspaper Editorials. Coherence Strategy is one where the elements strategy and reinforce each other thematic progression the pattern: linear, derived, and constant progression. A coherence strategy produces more value, with each element of the strategy producing more because of the present of the other elements. but in this research just restricted three pattern.

There are studies on these topics such as from Wei (2016). It analyzed the speakers and writers organize their messages in a way which make them integrate into the unfolding text smoothly and it makes a significant contribution to the coherence of a text. It can connections that listeners' or readers' perception in a written or oral text.

The second research on this topic was conducted by Eva's (2013) She found thematic progression letter analysis on Reader's forum in Jakarta Post. She found that: 1) Zigzag Theme, 2) Re-iterate theme, 3) Blending between those thematic development and 4) No thematic development.

The last study on this topic was conducted by Valeria (2015) she analyzed The schematic structure of news item text. Newspaper and article text from Jakarta Post. She 
found the similarity of texts is used for declarative mood type in the two tests, but there is only one interrogative mood type found in The Jakarta Post (TJP).

The studies above are important research to know about the thematic progression. However, there is no comparative

1. What are the common pattern of Thematic Progression in Jakarta Postnewspaper editorials?

2. What are the common pattern of Thematic Progression in 'Kompas' newspaper editorials?

3. What are the different (if available) between the thematic progression pattern in Jakarta Post and 'Kompas'newspaper editorials?

\section{METHOD}

research was genre-based study can be categories as mix method study.
Post and 'Kompan objective of this study was Thematic progression in Jakarta
Post and objective, the current study employed Jakarta Post and 'Kompas' newspaper editorials based on the research method with pattern-based approach.

The data of this study were taken from 20 texts newspaper editorial (10 texts Jakarta Post and 10 texts 'Kompas' newspaper editorials). That was quite understandble since the practice done so far, as interest to read newspaper editorials, The editorials language was usually formal as they directed at a reading public who is already informal about current events but who wishes to read about the wider implications of events in news. The various formality of the language, however, from a large newspaper to a small provincial newspaper. More importantly, the language of editorials is persuasive. Therefore, it dragged the writer to employ only Thematic Progression in Jakarta Post and ' Kompas' newsapaper editorials. study were summarized in Table 3.1 below.

\section{Table 1. The distribution of the newspaper editorials}

\begin{tabular}{|c|l|c|c|c|}
\hline No & Newspaper & Code & F & \% \\
\hline 1. & Jakarta Post & JP & 10 & 50 \\
\hline 2. & 'Kompas' & K & 10 & 50 \\
\hline \multicolumn{2}{|c|}{ Total } & & 20 & 100 \\
\hline
\end{tabular}


As indicate in table 1 the convient samples 20 texts newspapers editorials were selected. Ten were from Jakarta Post and ten were from' Kompas'. The distribution of the newspaper editorials, as presented in table 3.1. Respresents the distribution of Thematic Progression in Jakarta Post and 'Kompas' newspaper editorials and selected based on purposive sampling technique. Only the Thematic Progression in Jakarta Post and 'Kompas' newspaper editorials.

The newspaper editorials were randomly obtained through the writer's consent and taken from Jakarta Post and 'Kompas' newspapers in Indonesia. The decision about the number of 20 editorials included Jakarta Post and ' Komaps' newspaper editorials. The minimum requirement for number of text to be included in a quantitative analysis was 20 texts. In additions, another reason for selecting 20 newspaper editorials was also made based on the assumption that this present study on only editorials, so that the number of 20 texts newspaper editorial.

The research object was the text appeared in the Jakarta Post and 'Kompas' Newspaper Editorials. The research was common pattern Thematic progression in Jakarta Post and 'Kompas' Newspaper Editorials. The Total object of reading texts taken from 10 texts in Jakarta Post and 10 texts from 'Kompas' newspaper editorials. The Total object were 20 Texts.

The sequence of the research procedures will be followed: First Collect the texts in Jakarta Post and 'Kompas' newspaper editorials. Second Give the code and number at Editorials in each text. Third, Find theme and rheme in reading text as the object on analysing. The data were Jakarta Post 10 texts and 'Kompas' 10 texts in Newspaper Editorials, so Total were 20 Texts. Fourth Marked Thematic Progression (Theme and Rheme) all texts in Jakarta Post and 'Kompas' newspaper editorials. Fifth Identify the text based pattern Thematic Progression of the text and classified the text as Pattern taken the common pattern. Sixth Checklist the of the all object ( 20 Texts ) based the patterns thematic progression in table intrument. Seventh Analyze the all object, so that the data was comparison research and coresearch common pattern thematic progression in Jakarta Post $\mathrm{n}$ 'Kompas' Newspaper Editorials.

Since this study concerns three genres analysis, the research was employ a checklist contain newspaper editorials as the main instrument in analyzing the data. The newspaper editorials employed for analyzing the text sections of the thematic progression in Jakarta Post and 'Kompas' Newspaper editorials of patterns was draw or pattern from Danes (1974).

The instrument in this research was checklist the table instrument after the text finish Marked Thematic Progression (Theme and Rheme) in the text continue the 20 texts with instrument checklist. The research draw a table containing the texts, and based the pattern of the texts which will analyzed by research and co-research. Co-research was Eka Puspita. She was the college student S2 Bahasa Inggris UNIB. 


\section{Table 2. Checklist/Instrument of Text Thematic Progression inNewspaper Editorial}

\begin{tabular}{|c|c|c|c|c|c|c|c|c|c|c|c|c|c|c|c|c|c|c|c|c|c|}
\hline \multirow{3}{*}{ Patterns } & \multirow{3}{*}{ Representative Keywords } & \multicolumn{20}{|c|}{ Editorials } \\
\hline & & \multicolumn{10}{|c|}{ Jakarta Post } & \multicolumn{10}{|c|}{ Kompas } \\
\hline & & 1 & 2 & 3 & 4 & 5 & 6 & 7 & 8 & 9 & 10 & 1 & 2 & 3 & 4 & 5 & 6 & 7 & 8 & 9 & 10 \\
\hline $\begin{array}{l}\text { 1. Linear } \\
\text { Progression }\end{array}$ & $\begin{array}{l}\text { 1a. Theme realtes to the } \\
\text { Rheme of the preceding } \\
\text { utterance, and in other } \\
\text { words, the Rheme portion } \\
\text { of each sentence } \\
\text { 1b. Occur frequency in } \\
\text { expository and } \\
\text { argumentative texts }\end{array}$ & & & & & & & & & & & & & & & & & & & & \\
\hline 2. Derived Theme & $\begin{array}{l}\text { 2a. The topic of each } \\
\text { sentenceare individually } \\
\text { deifferent, but are all } \\
\text { derived from the same } \\
\text { 2b. Hypertheme or overall } \\
\text { theme of a paragraph or } \\
\text { text as illustrated }\end{array}$ & & & & & & & & & & & & & & & & & & & & \\
\hline $\begin{array}{l}\text { 3.Constant } \\
\text { progression }\end{array}$ & $\begin{array}{l}\text { 3a. The Same theme appears in } \\
\text { a series of ulttrance } \\
\text { 3b. Involves the following } \\
\text { relevant relations }\end{array}$ & & & & & & & & & & & & & & & & & & & & \\
\hline
\end{tabular}

(Danes 1974)

In this research, the data was collected by using documentation. According to Arikunto (1998), documentation method collects the data about variable from newspaper, note, book, magazine, etc. The documtation is the 10 texts in Jakarta Post and 10 texts in Kompas editorials. In collecting the data, the researcher used co-researcher to avoid faultiness, and doubtless. (Hopkin, 1993) suggested that the researcher can use partnership or collaborative observation which is particularly relevant. He also said that partner must be somebody with whom the researcher can work comfortably. The researcher used co-researcher who has an experience about the subject being investigated. The research and co-research first filling the marked appropriate with the procedures.

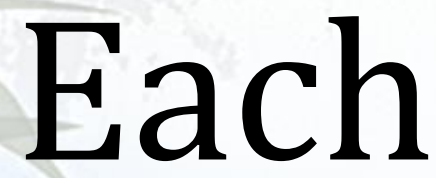

of reading text was to get the general meaning or impression of content. After then, each reading was analyzed by marking the pattern classified as Theme and Rheme text which appreared in the Jakarta Post and 'Kompas' newspaper editorials. All the marked were collected and tabulated according to the giving concept.

The comparison between two research and coresearch analyzed by using reliability technique. To see whether the checklist was reliable or not, research used inter rater reliability. Weir (1993) said that inter rater reliability refers to the degress is similarity between different examiner. It is often that work marked indenpendently by two different markers, with their being averaged. This reliability measured a correlation coefficient.

In this research the technique for Analyzing data:Certify the keyword of each pattern Linear
Progression, Derived Theme and Constant Progression, the results of identication in the cumulative or summing based on the progression pattern, Rejection based the pattern Linear Progression, Derived Theme and Constant progression, Identify and calculate the most frequently used patterns in Jakarta Post and 'Kompas' Newspaper editorials,

Finding/identifying the difference of progression 
pattern between text in Jakarta Post and 'Kompas'.

To achieve the reliability of data analysis, this study employed data tringulation analysis in which inter-rater reliability analyis was concluded. This to ensure the reliability of the textual analysis where all of these texts were all the texts choosen from the newspaper editorial and analyzed by an expert as an independent rater, so that different individuals can identify the boundry of communicative pattern at a sufficiently hight level

The co-research was trained who to code the text into its possible communicative pattern with the use of research instrument as previously explained in order to assure that the co-research clearly understood how to code the Newspaper Jakarta Post and 'Kompas' section. Then, the coresearch was asked to identify the possible moves selected newspaper and if any miscodingart

occurredthen discussion, negotiation and clarification will be held in order to reach an agreement between the research and co-research. Last, the co-research was work independently it codeall texts. The 10 texts Jakarta Post and 10 texts 'Kompas' the Total 20 Texts.

Then she was trained to identify thematic progression in Jakarta Post and 'Kompas' newspaper editorial in marked theme and Rheme in text newspaper editorial and conclused by pattern Thematic Progression taken thecommon based the pattern after then using the checklist based on pattern by Danes (1974). The co-research was given 20 texts Jakarta Post and 'Kompas' newspaper editorials selected from 20 of texts Jakarta Post and 'Kompas' newspaper editorials. She classified all text based pattern Thematic Progression using the checklist based on Danes (1974). Finally, the result of inter rater/coder analysis as cited in Kanoksilapatham (2005) to ensure correspondence in the identification of pattern. The percent agrrement was calculated using the following formula:

$$
\frac{\mathrm{A}}{(\mathrm{A}+\mathrm{D})} \mathrm{X} 100 \%
$$

Where:

$A=$ the number of agreements

$\mathrm{D}=$ the number of disagreements (Dobahkti, 2011)

To know the data strengt agreement, the scale value is formulated as follow:

Table 3. Interpretation of Cohen's Kappa

\begin{tabular}{|c|c|c|}
\hline Value of Kappa & Level of Agreement & \% Data that are Reliable \\
\hline $0-20$ & None & $0-4 \%$ \\
\hline $21-39$ & Poor & $3-15 \%$ \\
\hline $40-59$ & Fair & $15-35 \%$ \\
\hline $60-74$ & Good & $35-63 \%$ \\
\hline $75-90$ & Excellent & $64-81 \%$ \\
\hline Above 90 & Almost Perfect & $82-100 \%$ \\
\hline
\end{tabular}


Through this calculation, the correlation between the research and co-research coding for each text newspaper editorial. The coficient analysis of Cohen's Kappa as cited in Kanoksilapatham (2005) was presented in figure 3.3. it was where the Cohen's Kappa has an upper limit of 1.00 and a lower limit od 0.00 (Brown, 1996). The rules for the interpretation of Cohen's Kappa are summarized as follows: less than 0.40 is poor, $0.40-0.59$ is fair, 0.60 0.74 is good, and more than 0.75 is excellent (Kanoksilapatham (2005).

\section{RESULTS AND DISCUSSION}

There were 20 texts newspaper editorials theses analyzed in this study. Ten were selected from Jakarta Post (JP) and ten were 'Kompas' (K) newspaper editorials. To measure the reliability of the textual analysis, this study employed data trigulation analysis. As shown in table 4 . The result of the inter-coder reliability analysis showed 95\% agreement between research and co-research. It indicated that there was a high agreement between research and co-research which implies that the reliability of the result can be accepted.

Table 4. The result difference of research and co-research reliability analysis

\begin{tabular}{|c|l|c|c|c|c|}
\hline No & \multicolumn{1}{|c|}{ Pattern } & Total Text & Agreed Analysis & $\begin{array}{c}\text { Cohen's } \\
\text { Kappa }\end{array}$ & Persentage \\
\hline 1. & Linear Progression & 20 & 2 texts & .10 & $10 \%$ \\
\hline 2. & Derived Theme & 20 & 10 texts & .50 & $50 \%$ \\
\hline 3. & Constant progression & 20 & 7 texts & .35 & $35 \%$ \\
\hline \multicolumn{2}{|c|}{ Total } & 19 texts & .95 & $95 \%$ \\
\hline
\end{tabular}

From table 4 above there are results research and co- research reliability analysis Thematic Progression in Jakarta Post newspaper editorials. First, tommon pattern is Derived Theme 10 texts (50\%). Second, common is Constant Progression 7 texts (35\%) and third, common pattern is Linear progression 2 texts (10\%). The totals agreed analysis research and co-research were reached (95\%) covering 19 texts. It meant the reliability result was high and accepted.

The first analysis in this study is focused on occurrence possible of Thematic Progression in Jakarta Post newspaper editorials. The data analysis results revealed that the Thematic Progression as are presented in table 5 below:

Table 5. Thematic Progression in Jakarta Postnewspaper editorials

\begin{tabular}{|c|l|c|c|}
\hline No & \multicolumn{1}{|c|}{ Pattern } & Frequency & Percentage \\
\hline 1. & Constant progression & 5 texts & $50 \%$ \\
\hline 2. & Derived Theme & 4 texts & $40 \%$ \\
\hline 3. & Linear Progression & 1 text & $10 \%$ \\
\hline \multicolumn{2}{|c|}{ Total } & 10 Texts & $100 \%$ \\
\hline
\end{tabular}


As can be noticed in Table 5. The common pattern of thematic progression in Jakarta Post newspaper editorials was Constant progression. It meant the Constant Progression was reached (50\%) covering 5 texts. Constant Progression result was high and accepted from the other pattern.

The second analysis in this study is on identifying which common pattern of Thematic Progression in 'Kompas'newspeapr editorials are Constant progression, Derived Theme, and Linear The results are presented in table 6 below:

Table 6. Thematic Progression in 'Kompas' newspaper editorials

\begin{tabular}{|c|l|c|c|}
\hline No & \multicolumn{1}{|c|}{ Pattern } & Frequence & Percentage \\
\hline 1. & Derived Theme & 6 texts & $60 \%$ \\
\hline 2. & Constant progression & 3 texts & $30 \%$ \\
\hline 3. & Linear Progression & 1 text & $10 \%$ \\
\hline \multicolumn{1}{|c|}{ Total } & 10 texts & $100 \%$ \\
\hline
\end{tabular}

As can be noticed $\mathrm{n}$ Table 6. The Common pattern of thematic progression in 'Kompas' newspaper editorials are Derived Theme were reached $(60 \%)$ covering 6 texts. It meant more than half occur the pattern Derived Theme the frequence $60 \%$.

The common Pattern of the Thamatic Progression in Jakarta Post and 'Kompas'newspaper editorials: Ten Texts Jakarta Post and Ten texts 'Kompas' newspaper editorials in defferent texts of authors have been analyzed in this research, There are three possible pattern of review Jakarta Post newspaper editorials, there are pattern: 1) Linear Progression, 2) Derived Theme, 3) Constant Progression. The analysis results are show in Table 7 below.

The analysis results presented with follows table.

Table 7. Thematic Progression in Jakarta Post and 'Kompas' newspaper editorials.

\begin{tabular}{|c|l|c|c|c|c|}
\hline \multirow{2}{*}{ No } & \multirow{2}{*}{ Pattern } & Jakarta Post Newspaper & 'Kompas' Newspaper & \multicolumn{2}{|c|}{ Total } \\
\cline { 3 - 7 } & & Freq & Freq & Freq & $\%$ \\
\hline 1. & Derived Theme & 4 texts & 6 texts & 10 & 50 \\
\hline 2. & Constant Progression & 5 texts & 3 texs & 8 & 40 \\
\hline 3. & Linear Progression & 1 text & 1 text & 2 & 10 \\
\hline \multicolumn{2}{r|}{} & 10 texts & 10 texts & 20 & 100 \\
\hline
\end{tabular}

In Table 7. There were some sholarship between Jakarta Post and 'Kompas' newspaper in using thematic progression. Such as both of them use use three types of thematic progression, for example. Derived Theme, Constant Progression and Linear Progression. Both of them used Derived Theme on general implantation on writing the news for their media. 


\section{Discussion}

$10 \begin{aligned} & \text { first objective of this } \\ & \text { research is the } \\ & \text { common pattern of }\end{aligned}$

Thematic Progression in Jakarta post newspaper editorials. The results showed that all 10 texts. All were newspaper editorials adopted three pattern proposed by Danes (1974). Including Pattern Linear progression, Derived Theme and Constant Progression. The common pattern of Thematic Progression in Jakarta Post newspaper editorials. That in text was the most common pattern Constant Progression. It seems progression not in accordance with the described in the sequence by (Danes 1974). Between pattern Derived Theme and Linear progression. Constant progression command pattern in Jakarta Post newspaper editorials. It meant half form 10 text occur the pattern Constant Progression the frequence $50 \%$ and Derived Theme the frequence $40 \%$.

The adventages the Constant Progression was successive clauses retairn the same there or referent in initial times on problems within the labour party. Adventages Derived theme will followed the themes connect to implict overall 'Hypertheme' of the whole text and adventages Linear progression is a logical means of creating cohesion is logical means of creating cohesion but less obtrusive than constant progression. It may however seem plodding it overused. According Danes (1974) Pattern Constant Progression, a constant progression where the theme is kept from clause to clause.This mean that the Jakarta Post newspaper editorials used a simple pattern because it rarely used a pattern Linear Progression.

The second objective of this research was to common pattern of Thematic Progression in 'Kompas' newspaper editorials. The results shown that all 10 texts. All were newspaper editorials adopted three pattern proposed by Danes (1974). Including Pattern Linear progression, Derived Theme and Constant Progression. The common pattern of Thematic Progression in 'Kompas' newspaper editorials. The text was the most common pattern Derived Theme. It seems progression not in accordance with the described in the sequence by (Danes 1974). Between pattern Constant Progression and Linear progression. Derived Theme command pattern in 'Kompas' newspaper editorilas. It meant more than half occur the pattern Derived
Theme the frequence $60 \%$ and Constant Progression the frequence $30 \%$.

The adventages of derived themes were connected to implict overall 'Hypertheme' of the whole text, adventages the Constant Progression, successive clauses retairn the same there or referent in initial times on problems within the labour party and adventages of Linear progression was a logical means of creating cohesion logical means of creating cohesion but less obtrusive than constant progression. It may however seem plodding it overused. According Danes (1974) Pattern Derived Theme, a progression where each theme is derived from a more general macro-theme. This mean that the Jakarta Post newspaper 
editorials used a simple pattern because it rarely used a pattern Linear Progression.

The last objective, The different between the thematic progression pattern in Jakarta Post and 'Kompas' newspaper editorials. Difference, thematic progression pattern in Jakarta Postare Constant and Derived Theme. Where as thematic progression pattern in 'Kompas' are Derived Theme. Its means the some differences of Thematic Progression pattern between Jakarta Post and 'Kompas' pattern progression, In Jakarta Post are Constant Progression and Derived Theme in 'Kompas' are Derived Theme and Constant Progression. This means that both of these newspaper chose to use a simple pattern, and rarely using pattern Linear Progression. This is probably in Jakarta Post and 'Kompas' newspaper editorials caused or in the intention of ease readers and interested in reading editorials or probably readersearly read newspaper.It means that the writer of "editorials in Jakarta Post and 'Kompas' mostly dominant the texts by using derived theme and constant progression. it is informative, easier and understand.

The current finding of justifying research based on the knowledge gaps is also difference Jing Wei (2016). It analyzed the speakers and writers organize their messages in a way which make them integrate into the unfolding text smoothly and it makes a significant contribution to the coherence of a text. It can connections that listeners' or readers' perception in a written or oral text. The contrast, the way for justifying the research project based on the knowlege gap in newspaper editorial of the this study difference from the finding of Eva's (2013) She found thematic progression letter analysis on Reader's forum in Jakarta Post. The finding were: 1) Zigzag Theme, 2) Re-iterate theme, 3) Blending between those thematic development and 4) No thematic development. The way for justifying the research project based on the knowlwdge gap found The Thematic Progression in newspaper editorial of this study were diffrence of the finding in the last study on Valeria (2015) she analyzed The schematic structure of news item text. Newspaper and article text from Jakarta Post. She found the similarity of texts is used for declarative mood type in the two tests, but there is only one interrogative mood type found in The Jakarta Post (TJP).

\section{CONCLUSION AND SUGESTION}

Since this research concern in investigating the pattern in thematic progression, Thematic Progression in Jakarta Post and 'Kompas' Newspaper Editorials.the out put of this research was conclude the most frequent pattern of text in the neswpapers. Based on the finding of thematic progression analysis. Several conclusions could be draw pattern from this study. In term of the thematic system, it was found that two patterns of thematic progression are employed in newspaper editorials. First, common pattern of
Thematic Progression in Jakarta

Postnewspapereditorials are Constant Progression and Derived Theme. Second, common patternof Thematic Progression in 'Kompas' newspaper editorials are 
Derived Theme and Constant Progression. Finally, Derived Theme and difference on thematic progression pattern in Jakarta Post Constant Progression. The and 'Kompas'newspaper editorials. In the Thematic Progression in Jakarta post newspaper editorials are Constant Progression and Derived Themewhere as the Thematic Progression in 'Kompas' newspaper editorials are diffrerences exist in the order of patterns of topic progression.

\section{SUGGESTION}

Based on the finding and the conclusions, the research would like to contribute some suggestions:

1. For the teachers. It can be reference for teaching mainly in application of language element about thematic progression. It is as implication of the theories to practice in using thematic for mass media writing and reading as sampling for using it.

2. For the students. It is as example for using thematic progression in daily life. Students were more understand for its implantation clearly.

\section{REFERENCES}

Arikunto,Suharsimi.1998.Prosedur penelitian Suatu Pendekatan Praktek. Jakarta: RinekaCipta.

Alice Caffarel-Cyron\&elizabethRechniewski. 2014. Exploring the generic structure of french editorials from the perspective of systemic functional linguistics, Journal of world language.

Brown, H Douglash. 1994. Teaching by principles: An Interactive Approach to Language Pedagogy.San Fransisco: Prentice Hall Regent.

Danes, F. 1974. Fungsional Sentence Perspective and the Organization of the Text.In papers on Functional Sentence Perspective, by F. Danes, The Hague. Mouton

Eggins, S. 2004. An introduction to systemic functional linguistics.London: Continuum.

Escholz, Paul and alfred, Rose. Subject and Strategy, a Rhetoric Reader. New York: St. Martin's Press (1985)

Eva's 2013.Thematic Development of Letters on Reader's Forum in the Jakarta Post Published in February 2013.

Forey, G. 2002.Aspects of theme and their role in workplace texts.Unpublished Ph.D. thesis.University of Glasgow, Glasgow.

Fries, P.H. 1995.Themes, methods of development and Texts. In On subject and theme: From the perspective of functions in discourse, ed. R. Hasan, and P. Fries, 317-359. Philadelphia: John Benjamins. 
Glass, G.V., \&Hoplins, K.D. 1984. Statistical methods in education and psychology.Englewood Cliffs, NJ: Prentice Hall.

Ghadessy, M. 1995. Thematic development and its relationship to registers and genres.In Thematic development in English text, ed. M. Ghadessy, 129-146.London: Pinter.

Halliday, M.A.K. 2014.An introduction to functional grammar (4th ed.). Revised by C. M. I. M. Matthiessen.New York: Routledge.

Halliday, M.A.K. 2004.An introduction to functional grammar (3rd ed.). Revised by C. M. I. M. Matthiessen.London: Arnold.

Halliday, M.A.K. 1994. An Indtroduction to Functional Grammar.2nd Ed. London: Arnold.

Halliday, M.A.K., and R. Hasan.1985. Language, context and text: aspects of language in a social semiotic perspective. Geelong: Deakin University Press.

Halliday, M.A.K and Hasan, R. 1976. Cohesion in English. London: Longman

Halliday, M.A.K. 1978.Language as Social Semiotic: The Social Interpretation of Lnaguage and Meaning.London: Edward Arnold.

Halliday, M.A.K. 1994. An Indtroduction to Functional Grammar.2nd Ed. London: Arnold.

Herriman, J. 2011. Themes and theme progression in Swedish advanced learners' writing in English. Nordic Journal of English Studies 10: 1-28.

H.J.X. Fernandes, 1984. Testing and Measurement.Jakarta Nasional Education Planning.

Hopkins, D.1993. A teacher's Guide to Classroom Research. 2nd edition.

Jing Wie.2016 Theme and Thematic Progression in Chinese College Students's English Essay. Media Singapore

Kanoksilapatham, B. 2005. Rhetorical Structure of Biochemistry Researcher Article. English for Specific Purposes, v24 n3, 169-292

Martin, J. 1992. English text.Amsterdam/Philadelphia: John Benjamins.

Martin, J.R. 1995. More than what the message is about: English Theme. In Thematic development in English, ed. M. Ghadessy, 223-259.London/New York: Printer.

McCabe, A. 1999.Theme and thematic patterns in Spanish and English history text (Unpublished doctoral dissertation).Aston: Aston University.

Mauranen, A. 1993a.Cultural differences in academic rhetoric: a textlinguistic study. Frankfurt am Main: Peter Lang.

Mauranen, A. 1993b.Contrastive ESP rhetoric: metatext in Finnish-English economics texts. English for Specific Purposes 12: 3-22. 
Thompson, G. 2004. Introducing functional grammar, 2nd ed. London: Arnold.

Thompson, G. 2014. Introducing functional grammar, 3rd ed. Abingdon: Routledge.

Wang, L. 2007. Theme and rheme in the thematic organization of text: Implications for teaching academic writing. Asian EFL Journal 9(1): 164-176.

Weir, C.J. 1983.Identifying the language needs of overseas students in tertiary education in the United Kingdom.Upublished.Ph D Thesis, University of London.

Yang, X. 2008.Thematic progression analysis in teaching exploration writing. English Language Teaching 1(1): 29-33. 463 Theoretical Background.

Van Dijk, T.A. 1996. Opinion and ideologies in Editorials', Second Draft March 1996. Paper for 4th International Symposium of critical Discourse Analysis, Language, Social life and Critical Thought, Athens 1995, and 2006.

Valeria's. 2015. A genre analysis of news Item Texts in the Jakarta Post and New York Times. 